\title{
The Study of Teaching Chinese as a Second Language Based on Mobile Assisted Language Learning
}

\author{
Wu Cai \\ Overseas Education College, Xiamen University, Xiamen, China \\ totc1003@163.com
}

\begin{abstract}
Keywords: Teaching Chinese as a second language; Mobile assisted language learning; Teachers; Teaching materials; Teaching methods
\end{abstract}

\begin{abstract}
With the deepening of globalization and rapid growth of China's economy, more and more people start to learn Chinese all around the world in recent years. Meanwhile, wide application of mobile devices and the rapid development of mobile technology help Chinese L2 (second language) learners to change the traditional approach of learning and turn to use the smartphone, tablet, or other mobile devices to study Chinese. The paper begins with a brief introduction of the development of mobile assisted language learning (MALL), then discusses how to integrate MALL into teaching Chinese as a second language (TCSL) from three aspects of teachers, teaching materials and teaching methods, and presents the significance of teaching Chinese as a second language based on MALL.
\end{abstract}

\section{Introduction}

In recent years, the number of Chinese L2 learners grows rapidly in the world. Statistically, the number of Chinese L2 learners all around the world reached 100 million in March, 2014. Meanwhile, according to the statistics from the Confucius Institute Headquarters, 134 countries (regions) have established 500 Confucius Institutes and 1000 Confucius Classrooms by December, 2015. With the growth in the number of Chinese L2 learners, the field of teaching Chinese as a second language is facing many new challenges. Under the background, it is particularly important to adopt the modern educational information technology to guide the Chinese teaching.

After experiencing web1.0 and web2.0 eras, it comes to the era of mobile Internet, which revolutionizes the educational mode. It is in line with the latest Horizon Report 2016, which highlighted the educational potentials of Bring Your Own Device (BYOD). [1] BYOD means People bring their own smartphones, tablet PC, laptop or other mobile devices to learn or work. The number of mobile connected devices is increasing at a high rate every year. It is obvious that the adoption of mobile devices with wireless network connectivity has already provided a new model for educational activities. Furthermore, more and more teachers and students accept the practices of mobile learning in universities and colleges all over the world.

Undoubtedly, mobile devices are becoming important learning and teaching terminals in educational context. Meanwhile, lots of mobile assisted language learning practices come out in the recent years. It is not difficult to find that mobile learning has become a hot point and front line gambit in the field of language education. If teaching Chinese as a second language is combined with mobile learning, it will create new vitality into teaching and learning activities of Chinese L2 learners. The paper illustrates the specific application of teaching Chinese as a second language based on MALL from the views of teachers, teaching materials and teaching methods. This paper will explore the significance of teaching Chinese as a second language based on MALL.

\section{Mobile Assisted Language Learning}

Since the early 1960s, the educational information technologies, containing computer assisted language learning (CALL), distance education technology and multimedia technology, have changed the educational mode and created new possibility for language teaching and learning. Garrett (1991) explored that educational technology could play a critical role in foreign language 
learning and its researches. [2] Furthermore, Kukulska-Hulme (2009) took technology as a kind of social and cultural phenomenon that could bring effective language learning. [3]

During the last twenty years, lots of smaller mobile devices with language learning functions have come into view. With the widespread ownership of mobile devices, People started to use digital dictionaries, MP3 players, mobile phones, PDAs, and tablets to learn language. In 1994, the first report about mobile assisted language learning was published in Canada. The positive influence of word processing with PDAs was described in that report. [4] As portable devices become so ingrained in people's lifestyles and daily activities, there is no doubt that the integration of mobile technologies into language teaching and learning has been more gradual. What kind of change can be happened to learning by new technology? Sharples, Taylor and Vavoula (2005) showed the characters of new learning and new technology. [5]New learning is personalized, learner-centred, situated, collaborative, ubiquitous and lifelong. New technology is personal, user-centred, mobile, networked, ubiquitous and durable. From that, it is clear that new learning and new technology are totally different from the traditional learning and the old technology. In other words, new learning and new technology will offer learners absolutely new learning experiences.

Some studies attempted to explore the definition of MALL. Yang (2013) thought MALL was an emerging subsection of computer assisted language learning. [6] He believed that MALL had been extensively explored in computer assisted language learning research and mobile devices could also be regarded as handheld 'computers' with a variety of functions. On the contrary, Kukulska-Hulme and Shield (2008) treated MALL different from computer assisted language learning because of its use of personal and portable devices brought new methods of language learning. [7] Moreover, mobile assisted language learning offered continuity of interaction and allowed language learning to happen in any places at any time. Duman, Orhon and Gedik (2015) also considered MALL as a special form of mobile learning and differed from computer assisted language learning because of its use of handheld devices. [8] There is still unclear definition of mobile assisted language learning now. However, researchers believe that the concept of MALL will be more clearly and stable through kinds of MALL practices and studies in the near future.

When mobile assisted language learning becomes more popular in recent years, scholars start to consider how effective mobile devices for language learning are. Sung et al. (2015) performed a meta-analysis to explore the effectiveness of mobile devices used for language learning. Finally, they found that mobile devices bring positive effect. More specifically, the proportion of students in the experimental team who learn language with the help of mobile devices exceeded their counterparts who had not use mobile devices to learn language is nearly $70 \%$. [9]

In conclusion, nowadays mobile technology has become one of the dominating trends of modern educational technological applications for language learning and has attracted language learners increasingly. It is a new attempt to integrate mobile technology into teaching Chinese as second language. Researchers believe that the integration of MALL into TCSL will help Chinese L2 learners to get more marked effects.

\section{Discussion of Integrating MALL into TCSL}

Teachers, teaching materials and teaching methods play major roles in the field of teaching Chinese as a second language. Jin (2009) pointed that it was necessary to emphasize the concepts of teachers, teaching materials and teaching methods in teaching Chinese as a second language. [10] Cui (2010) also believed that teachers, teaching materials and teaching methods were the eternal themes in language teaching. [11] Therefore, if MALL is integrated into teaching Chinese as a second language from three views of teacher, teaching materials and teaching methods, it will probably bring marked effects. Fig. 1 shows the framework for integrating MALL into TCSL. 


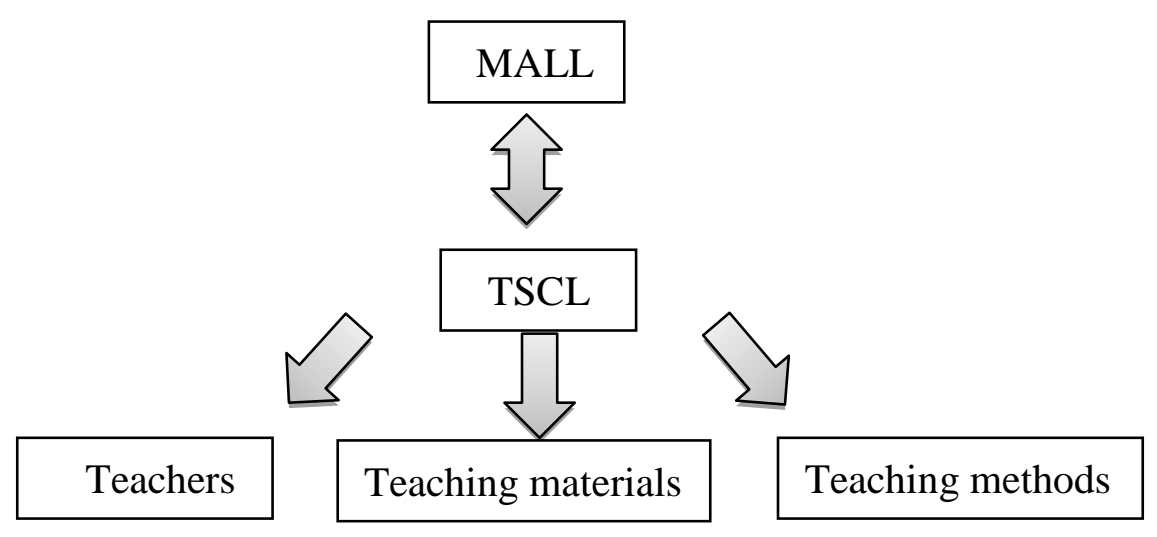

Figure 1. A Framework for Integrating MALL into TCSL

The Issue of Teachers. During the development of teaching Chinese as a second language, teachers play a key role. Teaching materials and teaching modes have close relationship with teachers. Teachers arrange the teaching materials and implement teaching methods. In other words, different kinds of teachers have their distinct teaching materials and teaching modes; therefore, researchers should give priority to the issue of Chinese L2 teachers.

Even if modern Chinese L2 teaching history can start back to the 1950s, extensive Chinese L2 teaching activities were just begun during the last three decades. Both in quantity and quality, Chinese L2 teachers are faced with different problems. Firstly, there are more than 100 million Chinese L2 learners all round the world nowadays. If one teacher teaches 20 students, at least 5 million Chinese L2 teachers are needed. The number of Chinese L2 teachers cannot meet the need of reality. The shortage of Chinese L2 teacher has gradually become a major bottleneck and restricted the sustainable development of teaching Chinese as a second language in the world. Secondly, the Chinese L2 teachers have various educational levels and abilities. In today's era of big data, Chinese L2 teacher should be more creative and keep up with the pace of modern teaching technology development. Particularly, Li (2015) pointed that it was necessary to improve Chinese L2 teachers' capability of applying the advanced modern teaching technology. [12]

Mobile technology, the new style of the modern educational technology, is beneficial to effective acquisition and processing of knowledge through spontaneous interactions and flexible modes. How to integrate the teacher with mobile technology is a key issue. Mobile learning technology is still at early stage of development. Stockwell (2008) suggested that the teachers should have patience and give sufficient time to the learners to be familiar with mobile learning technology. [13] Hence, the teachers should look objectively from the perspective of the learners. As mobile devices have different features, teachers need to develop their knowledge of what mobile devices are needed and how to apply them appropriately in education. [14] Kukulska-Hulme (2012) also put forward that teachers needed to develop themselves to match the potential of mobile learning technologies. [15] Combining the practice of teaching Chinese as a second language with UNESCO Policy Guidelines for Mobile Learning [16], we have three suggestions for Chinese L2 teachers.

1) The Chinese L2 teachers should exploit mobile learning technology in a fashion consistent with their concepts of teaching. Every teacher has his/her private theory of teaching. Using teachers' personalized mobile learning practice is helpful for teaching effect.

2) The Chinese L2 teachers should help students explore, acquire and apply the knowledge from the mobile devices. Mobile learning devices facilitate Chinese L2 learners to acquire a lot of learning resources by themselves. Under the guidance of teachers, Chinese L2 learners' Chinese learning activities based on MALL will be easier.

3) The Chinese L2 teachers should ensure which curriculum and lesson plans are available to teachers via mobile devices. It is useful to fulfill the potential of mobile learning technology and maximize its effectiveness of Chinese learning. 
The Issue of Teaching Materials. The teaching effect is greatly influenced by teaching materials. As the modern educational technology develops, the teaching materials have various forms gradually. In 2000, Wang already advised that we should modernize Chinese teaching textbooks for oversea Chinese learners. [17] Thornton and Houser (2005) also showed that mobile devices such as phones and PDAs could be effective tools for delivering foreign language learning materials to the learners. [18] Now in the mobile information era, the mobile learning technology can provide Chinese L2 learners with digital contents in a wide variety of choices, such as text, image, video, and so on. Viberg and Grönlund (2012) explored that educators needed to develop effective materials for mobile assisted language learning. [19]Effective mobile Chinese teaching materials from Internet are easily accessible to Chinese L2 learners by smart phones, tablets and other mobile devices with low cost. Above all, the Chinese knowledge through mobile Chinese teaching materials can provide Chinese L2 learners a new learning experience for study.

To better provide guidance for teaching Chinese to speakers of other Languages by mobile teaching materials, the paper summarizes the commonly used mobile devices and Chinese L2 teaching materials (Table 1). It shows that different mobile devices bring different learning medium and develop different Chinese language skills.

Table 1. Summary of Typical Mobile Devices and Chinese L2 Teaching Materials

\begin{tabular}{lll}
\hline Mobile Device & Media of Teaching Materials & Main Language Skills of Developing \\
\hline E-dictionary & Text & Reading \\
E-book reader & Text, Image & Reading \\
Audio/music player & Audio & Listening \\
Cellular phone & Text, Audio & Listening and Reading \\
Smart phone & Text, Image, Audio and Video & Listening, Speaking, Reading and Writing \\
Tablet PC & Text, Image, Audio and Video & Listening, Speaking, Reading and Writing \\
Laptop & Text, Image, Audio and Video & Listening, Speaking, Reading and Writing \\
\hline
\end{tabular}

From Table 1, it is clear that different mobile devices can offer different media of teaching materials and develop corresponding Chinese language skills. It is important to achieve a good balance between teachers' ideas and learners' needs. In other words, the usability of mobile Chinese L2 teaching materials should be assured. As a consequence, effective teaching materials for non-native Chinese speakers based on MALL can be developed.

The Issue of Teaching Methods. Traditionally, language teaching methods are restricted by space and time. However, nowadays Chinese L2 teachers can teach students out of classroom by mobile technology and devices without space and time restriction. Massive scale learning services delivered by mobile learning technology in authentic communication contexts have changed the learning styles. More importantly, it can be found that new features and applications have been added for each new mobile device. These developments have prompted teachers to take a pedagogical view towards mobile devices to promote teaching. Kukulska-Hulme (2005) pointed that mobile devices offered the opportunity to devise new teaching methods and draw on their unique characteristics, such as connectivity for communication and collaboration, storing information and location-awareness. [20] These technological characteristics of the mobile devices can enrich Chinese L2 teachers' teaching methods and make them have more communication channels with students. It is helpful to build a positive relationship between teachers and students.

It is easy to find that mobile assisted language learning is closed to some pedagogical approaches, such as activity theory, contextual learning, distributed cognition theory, and so on. In the view of pedagogical approaches, it is believed the most important significance of MALL lies in enhancing interaction between teachers and students both in the formal and informal learning environments. Kukulska-Hulme (2015) pointed that informal learning played a critical role in language learning and the mobile device ownership promoted its growth. [21] 
From this perspective, the teaching methods using mobile technology allow Chinese L2 learners to fulfill their potential through informal learning out of classroom. In other words, mobile learning can supply Chinese L2 learners with sufficient learning resources in different ways within a social setting. With increasing application of mobile learning technologies in informal language learning, it is believed that both Chinese L2 teachers and Chinese L2 learners can gain more sophisticated learning experience and more benefits.

\section{Summary}

With the rapid development of mobile technology and the wide use of mobile devices, the language learning styles are greatly changed. More and more language learners all around the world turn to use any kind of handheld mobile devices such as electronic dictionary, e-book reader, Mp3, smart phone, tablet PC, PDAs etc. in the study, including Chinese L2 learners.

The study introduces the current development of Chinese language learning in the world and mobile assisted language learning. By highlighting the integration of mobile assisted language learning (MALL) and teaching Chinese as a second language (TCSL) from three aspects of teachers, teaching materials and teaching methods, that the result shows that mobile learning is helpful for Chinese L2 teachers to teach, enhances the modes of Chinese L2 teaching materials and produces new Chinese L2 teaching methods. In the future, researchers will focus on finding the ways for achieving a good balance between MALL and traditional language learning; therefore, better effectiveness of teaching Chinese as a second language based on MALL will be gained.

\section{References}

[1] L. Johnson, S. Adams Becker, M. Cummins, V. Estrada, A. Freeman and C. Hall: NMC Horizon Report: 2016 Higher Education Edition. Austin, Texas: The New Media Consortium. (2016), p.36-37.

[2] N. Garrett: Technology in the Service of Language Learning: Trends and Issues, Modern Language Journal, Vol.75(1991), p.74-101.

[3] A. Kukulska-Hulme: Will Mobile Learning Change Language Learning? ReCALL, Vol.21 (2009) NO.2, p.157-165.

[4] J. Burston: Mobile-assisted Language Learning: A Selected Annotated Bibliography of Implementation Studies 1994-2012, Language Learning \& Technology, Vol.17 (2013)No.3, p.157-225.

[5] M. Sharples, J. Taylor and G. Vavoula: Towards a Theory of Mobile Learning, In Proccedings of MLearn 2005 Conference 25-28 October, Gape Town, South Africa. Available from: http://www.mlearn.org/mlearn2005/CD/papers/Sharples-\%20Theory\%20of\%20Mobile.pdf

[6] J. Yang: Mobile Assisted Language Learning: Review of the Recent Applications of Emerging Mobile Technologies, English Language Teaching, Vol. 6 (2013) No. 7, p.19-25.

[7] A. Kukulska-Hulme and L. Shield: An Overview of Mobile Assisted Language Learning: From Content Delivery to Supported Collaboration and Interaction. ReCALL, Vol.20 (2008) No.3, p. 271-289.

[8] G. Duman, G. Orhon and N. Gedik: Research Trends in Mobile Assisted Language Learning from 2000 to 2012, ReCALL, Vol.27 (2015) No.2, p.197-216.

[9] Y.-T. Sung, K.-E. Chang and J.-M. Yang: How Effective are Mobile Devices for Language Learning? A Meta-Analysis, Educational Research Review, Vol. 16 (2015) p.68-84.

[10] L.X. Jin: The Logic Analysis of the Three Notions: Teacher, Teaching Materials and Teaching Method, Language Teaching and Linguistic Studies, (2009)No.5, p.53-58. (In Chinese) 
[11] X.L. Cui: On the "Three Concerns" of Teaching Chinese as a Second Language, Chinese Teaching in the World, Vol.24 (2010) No.1, P.73-81. (In Chinese)

[12] C.L. Li: Some New IDEAS about the Teacher Training for International Chinese Education, Journal of Yunnan Normal University (Teaching and Research on Chinese as a Second Language Edition), Vol.13 (2015) No.1, P.63-70. (In Chinese)

[13] G. Stockwell: Investigating Learner Preparedness for and Usage Patterns of Mobile Learning. ReCALL, Vol.20 (2008) No.3, p. 253-270.

[14] A. Kukulska-Hulme and J. Traxler: Mobile Learning: A Handbook for Educators and Trainers (The Cromwell Press, Great Britain 2005) p.194.

[15] A. Kukulska-Hulme: Mobile-Assisted Language Learning. The Encyclopedia of Applied Linguistics, Published Online , 5 Nov, 2012.

[16] R. Kraut: UNESCO Policy Guidelines for Mobile Learning (United Nations Educational, Scientific and Cultural Organization, France, 2013)

[17] J.Q. Wang: On the Modernization of Chinese Language Textbooks for Overseas Learners, Applied Linguistics, (2000) No.34, p. 9-15. (In Chinese)

[18] P. Thornton and C. Houser: Using Mobile Phones in English Education in Japan, Journal of Computer Assisted Learning, (2005) No.21, p.217-228.

[19] O. Viberg and A. Grönlund: Mobile Assisted Language Learning: A Literature Review. In Proceedings of the 11th International Conference on Mobile and Contextualized Learning, (2012). Available from: http://ceur-ws.org/Vol-955/papers/paper_8.pdf

[20] A. Kukulska-Hulme and J. Traxler: Mobile Learning: A Handbook for Educators and Trainers (The Cromwell Press, Great Britain 2005) p.31.

[21] L.-H. Wong, M. Milrad and M. Specht: Seamless Learning in the Age of Mobile Connectivity (Springer Singapore, Singapore2015) p.281. 